\title{
Toxicity of Benthic Dinoflagellates Found in Coral Reef
}

\author{
Takeshi Yasumoto*1, Yasukatsu Oshima*1, Yasutaka MURAKami*1, \\ Ichiro NAKAJIMA*1, Raymond BaGNIS ${ }^{* 2}$, and Yasuwo FuKUYo*3 \\ (Received October 4, 1979)
}

\begin{abstract}
Five species of dinofiagellates and three microalgae of benthic habitat collected in French Polynesia were grown in unialgal state and tested for toxicity on mice and for hemolytic activity. Two diethyl ether soluble toxins (PL toxin-I, II) and one fast-acting toxin soluble in 1-butanol (PL toxin-III) were found in Prorocentrum lima. The chromatographic behaviors of PL toxin-I and II closely resembled those of scaritoxin and ciguatoxin prepared from ciguateric fishes. Potent hemolytic substance was present in Amphidinium sp. This species was also toxic to mice. No remarkable activity was detected in the following species: Coolia monotis, Amphidinium sp.-2, and Gymnodinium sp. (dinoflagellates); Chloococcopsis sp. and Isochrysis sp. (blue-green algae); and Nitzschia panduriformis (diatom).
\end{abstract}

A number of toxic animals have been reported to occur in coral reef areas ${ }^{1,21}$. Some of these animals are known or suspected to obtain their toxins from the diets of yet unidentified nature. Our discovery of Gambierdiscus toxicus as the probable cause of ciguatera provided the first example of the implication of a benthic dinoflagellate in the food chain transmittance of toxins in coral reef community ${ }^{3)}$. During that study it was also observed that many other species of dinoflagellates were present in the detrital and algal samples collected from coral beds. Since we occasionally found minor toxins in the gut contents of ciguateric fishes $^{4,5)}$ and since they may contribute to the complexity of human symptoms, it seemed important to test these species as the potential source of such toxins. Also there are toxins of unknown origin found in the grazing herbivores and detritus feeders such as the green turban-shell ${ }^{6)}$, turbanshell $^{7 !}$, and toxic crabs ${ }^{8,9 !}$. Thus, testing the toxin production by these dinoflagellates might help identify the source of these toxins. In view of the fact that some toxins of plankton origin, Prymnesium parvum and Gymnodinium breve toxins for example, are detectable more easily by hemolytic test than by mouse assay, screening by hemolytic activity was also conducted.

The present paper deals with the finding of two toxic dinoflagellates and the chromatographic properties of toxins found in Prorocentrum lima. Ad- ditional data are given to compare these toxins with ciguatoxin and scaritoxin prepared from fish.

\section{Materials and Methods}

\section{Culture}

The dinoflagellates were collected in 1978 from a brown alga Turbinaria ornata or a calcareous alga Jania sp. growing around Tahiti and the Gambier islands. They were grown unialgally in sea water medium enriched with ES-1 supplement ${ }^{101}$ at $25^{\circ} \mathrm{C}$ with illumination of $4000-8000 \mathrm{Lux}$ under $18 \mathrm{~h}$ light and $6 \mathrm{~h}$ dark cycles. All cultures were grown in 3-liter Fernbach flasks and harvested at the stationary growth phases. The following five species of dinoflagellates were tested in this study: Coolia monotis, Prorocentrum lima, Gymnodinium sp., and two species of Amphidinium. Two blue-green algae, Chloococcopsis sp. and Isochrysis sp., and a diatom Nitzschia panduriformis were also examined. Sites of isolation for the organisms are given in Table 1.

\section{Extraction and Fractionation of Toxins}

The cells collected by constant flow centrifugation (Sakuma 45CFS with $50 \mathrm{BCF}-3$ roter) at $8000 \mathrm{rpm}$ were suspended in $100 \mathrm{~m} l$ of methanol and treated with Ultra Turrax homogenizer (Janke $\&$ Kunkel) for $1 \mathrm{~min}$. The residue collected by centrifugation was treated twice in a similar manner.

*1 Laboratory of Food Hygiene, Faculty of Agriculture, Tohoku University, Tsutsumi-dori, Sendai 980

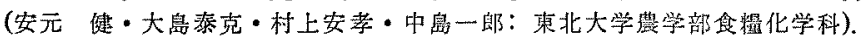

*2 Institut de Recherche Medicale "Louis Malarde", Papeete, Tahiti, French Polynesia (レイモンドバーニス：マラルデ医学研究所).

*3 Faculty of Fisheries, Kitasato University, Sanriku-cho, Iwate Prefecture 022-01 (福代㾭夫：北里大学水 産学部). 
The combined methanol extract was evaporated and the residue was subjected to partition between $100 \mathrm{~m} l$ of water and $300 \mathrm{~m} l$ of diethyl ether. Extraction of the aqueous phase was repeated twice with 200 and $100 \mathrm{ml}$ portions of diethyl ether. Further extraction of the aqueous phase was conducted thrice with 300,200 , and $100 \mathrm{~m} l$ portions of 1-buthnol. The residues obtained after evaporation of the diethyl ether, 1-butanol and water layers were used separately for bioassays.

\section{Mouse Assay}

The residues from the ether or butanol phases were suspended in $1 \%$ Tween 60 and those from aqueous phases were dissolved in deionized water. Toxicity was tested on mice by intraperitoneal route. Female mice of ddY strain weighing around $20 \mathrm{~g}$ each were used. The minimum amount of toxin required to kill a mouse within $24 \mathrm{~h}$ was defined as one mouse unit (MU).

\section{Hemolytic Test}

Serially diluted solutions of the samples were prepared with either ethanol or $0.9 \%$ saline. Each $50 \mu \mathrm{l}$ of test solution was mixed in a small centrifuge tube with $0.35 \mathrm{~m} l$ of saline and $0.5 \mathrm{~m} l$ of $2 \%$ suspension of mouse blood cells. After incubation for $1 \mathrm{~h}$ at $25^{\circ} \mathrm{C}$, the suspensions were centrifuged and examined for the concentration which caused complete hemolysis. In parallel with the samples similar test was run with standard saponin (Merck). Hemolytic activity shown by $1 \mathrm{mg}$ of the standard saponin was defined as one saponin unit (SU) and the hemolytic activity of the sample was expressed in terms of saponin unit of $1 \mathrm{mg}$ of the sample (SU/mg).

Chromatography
Our routine method $^{3)}$ for purification of cigautoxin was applied to the diethyl ether soluble toxins of $\boldsymbol{P}$. lima. The sample was successively treated on columns of silicic acid (100 mesh, Mallinckrodt), DEAE-cellulose (OH form, Brown), and Sephadex LH-20 (Pharmacia). Purification was further proceeded with a medium pressure chromatographic system employing the following conditions: adsorbent, LiChroprep RP-2 (Merck); solvent, methanol-water (4:1); glass column, 5 versus $500 \mathrm{~mm}$ in diameter and height; pressure, $20 \mathrm{~kg} /$ $\mathrm{cm}^{2}$; flow rate, $1.0 \mathrm{ml} / \mathrm{min}$. Location of the toxins in the eluent was performed by testing on mice.

Comparison of $\boldsymbol{P}$. lima toxins with ciguatoxin and scaritoxin was also conducted by thin layer chromatography (tlc) in the same way as employed in our previous study ${ }^{31}$. Plates of silica gel $\mathrm{H}$ (Merck) in $0.25 \mathrm{~mm}$ thickness were used in combination of the following two solvent systems: (1) chloroform-methanol-6 $\mathrm{N}$ ammonium hydroxide (90:9.5:0.5) and (2) benzene-1-butanol (75:25). After developing with the solvent, appropriate bands were scraped off from the plates. Each band was extracted with chloroform -methanol $(2: 1)$ solution and after evaporation of the solvent the residue was tested by intraperitoneal injection into mice.

\section{Results}

\section{Culture}

The size of the cultures, the cell density at the time of harvest, and the periods required for the harvest after inoculation are shown in Table 1. The typical example of growth curve for $P$. lima is shown in Fig. 1. P. lima showed strong tendency to adhere to the bottom of flasks with mucous substance.

Table 1. Culture of the organisms

\begin{tabular}{lcccc} 
Organisms*1 & $\begin{array}{c}\text { Total volume } \\
(l)\end{array}$ & $\begin{array}{c}\text { Culture period } \\
\text { (days) }\end{array}$ & $\begin{array}{c}\text { Cell density*2 } \\
\left(10^{4} \text { cells/ml) }\right.\end{array}$ & $\begin{array}{c}\text { Total obtained } \\
\left(10^{8} \text { cells) }\right.\end{array}$ \\
\hline Prorocentrum lima (Tahiti) & 14 & 21 & 1.0 & 1.4 \\
Coolia monotis (Tahiti) & 8 & 17 & 1.3 & 1.0 \\
Amphidintum sp. 1 (Gambier) & 24 & 13 & 7.1 & 17 \\
Amphidinium sp. 2 (Tahiti) & 16 & 13 & 2.0 & 3.2 \\
Gymnodinium sp. (Gambier) & 16 & 8 & 2.6 & 3.6 \\
Nitzschia panduriformis (Tahiti) & 16 & 13 & 3.1 & 5.0 \\
Chloococcopsis sp. (Gambier) & 4 & 30 & 600 & 240 \\
Isochrysis sp. (Gambier) & 4 & 30 & 180 & 112 \\
\hline
\end{tabular}

* 1 The name of island in parentheses indicates the site of isolation.

*2 At the time of harvesting. 


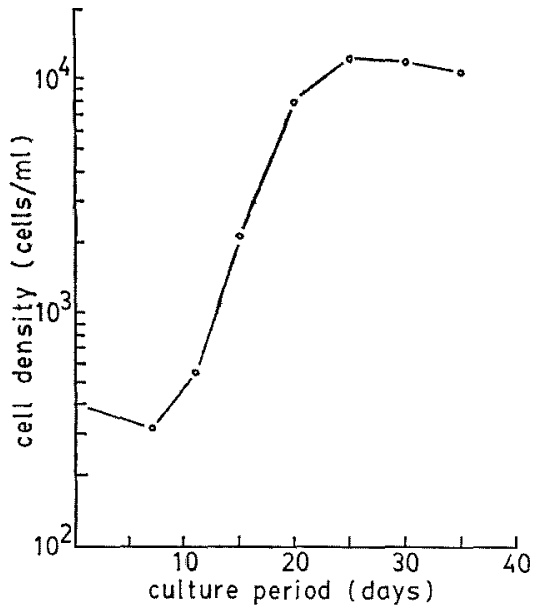

Fig. 1. Growth curve of Prorocentrum lima.

\section{Mouse Assay and Hemolytic Test}

The results of the mouse assay and hemolytic test are summarized in Table 2. Both diethyl ether and 1-butanol fractions of $P$. lima were significantly toxic to mice but each was observed to give different reactions to mice. The 1-butanol fraction killed mice quickly, normally within 30 min, while the ether soluble one acted more slowly. Toxicity was also recognizable in 1-butanol fraction of Amphidinium sp.-1 in lesser extent. The aqueous phases of both species did not contain toxin in any appreciable amount. No significant toxicity was observed in other species.

Amphidinium sp.-1 is proven to produce hemolytic substance(s) as indicated by the activities of ether and butanol soluble fractions in Table 2 . The specific activities of the fractions were 0.72 and $5.4 \mathrm{SU} / \mathrm{mg}$, respectively. At present stage, however, it is not certain if the two fractions contain the same components or different ones. The activity of 1-butanol fraction is comparable to $20.0 \mathrm{SU} / \mathrm{mg}$ observed in the same fraction of Prymnesium parvum in our laboratory which is known by its production of strong hemolysins. The activity of diethyl ether fraction of $C$. monotis is marginal.

\section{Chromatographic Properties of P. lima Toxins}

Toxins in the diethyl ether fraction of $P$. lima were not eluted from a silicic acid column with chloroform but with chloroform-methanol $(9 ; 1)$ solution. Upon treatment with DEAE-cellulose column, the toxicity was divided into two fractions: chloroform eluate and chloroform-methanol $(1: 1)$ eluate in an approximate ratio of $2: 3$. The former with less polarity was designated PL toxin-I and the later PL toxin-II. The two toxins were easily separable by tlc. The chromatographic properties of PL toxin-I and II are summarized in Table 3. Comparable data for scaritoxin and ciguatoxin are also attached in the same Table. It will be noticed that there are close resemblances between PL toxinI and scaritoxin and also between PL toxin-II and ciguatoxin. The mouse assay indicated that the minimum lethal doses for semi-purified specimens of PL toxin-I and II were $250 \mu \mathrm{g} / \mathrm{kg}$ and $490 \mu \mathrm{g} / \mathrm{kg}$, respectively. The fast-acting toxin of $P$. lima was not eluted from a silicic acid column with chloroform-methanol (1:1) solution but with methanol. As it was distinctly different from the ether soluble toxins, the acute toxin was named PL toxin-III.

\section{Discussion}

Many studies have been done to test the toxin

Table 2. Toxicity and hemolytic activity of the cultured organisms ${ }^{* 1,2)}$

\begin{tabular}{|c|c|c|c|c|}
\hline \multirow{2}{*}{ Organisms } & \multicolumn{2}{|c|}{$\begin{array}{l}\text { Toxicity to mouse } \\
\left(10^{-8} \mathrm{MU} / \mathrm{cell}\right)\end{array}$} & \multicolumn{2}{|c|}{$\begin{array}{l}\text { Hemolytic activity } \\
\quad\left(10^{-8} \mathrm{SU} / \text { cell }\right)\end{array}$} \\
\hline & $\begin{array}{l}\text { Ether soluble } \\
\text { fraction }\end{array}$ & $\begin{array}{l}\text { Butanol soluble } \\
\text { fraction }\end{array}$ & $\begin{array}{l}\text { Ether soluble } \\
\text { fraction }\end{array}$ & $\begin{array}{l}\text { Butanol soluble } \\
\text { fraction }\end{array}$ \\
\hline Prorocentrum lima & 143 & 71 & ND & ND \\
\hline Coolia monotis & ND & ND & 2.0 & ND \\
\hline Amphidinitum sp. 1 & ND & 6.0 & 3.8 & 14.5 \\
\hline Amphidinium sp. 2 & ND & ND & ND & ND \\
\hline Gymnodinium sp. & ND & $\mathrm{ND}$ & $\mathrm{ND}$ & ND \\
\hline Nitzschia panduriformis & $\mathrm{ND}$ & ND & ND & ND \\
\hline Chloococcopsis sp. & ND & ND & $\mathrm{ND}$ & ND \\
\hline Isochrysis sp. & ND & ND & ND & ND \\
\hline
\end{tabular}

*1 The water soluble fractions of all the species tested were negative both in toxicity and hemolytic activity.

*2 ND: Toxicity to mouse $<5.0 \times 10^{-8} \mathrm{MU} /$ cell; Hemolytic activity $<2.0 \times 10^{-8} \mathrm{SU} / \mathrm{cell}$. 
Table 3. Comparison of chromatographic behaviors of PL toxin-I and II with scaritoxin and ciguatoxin

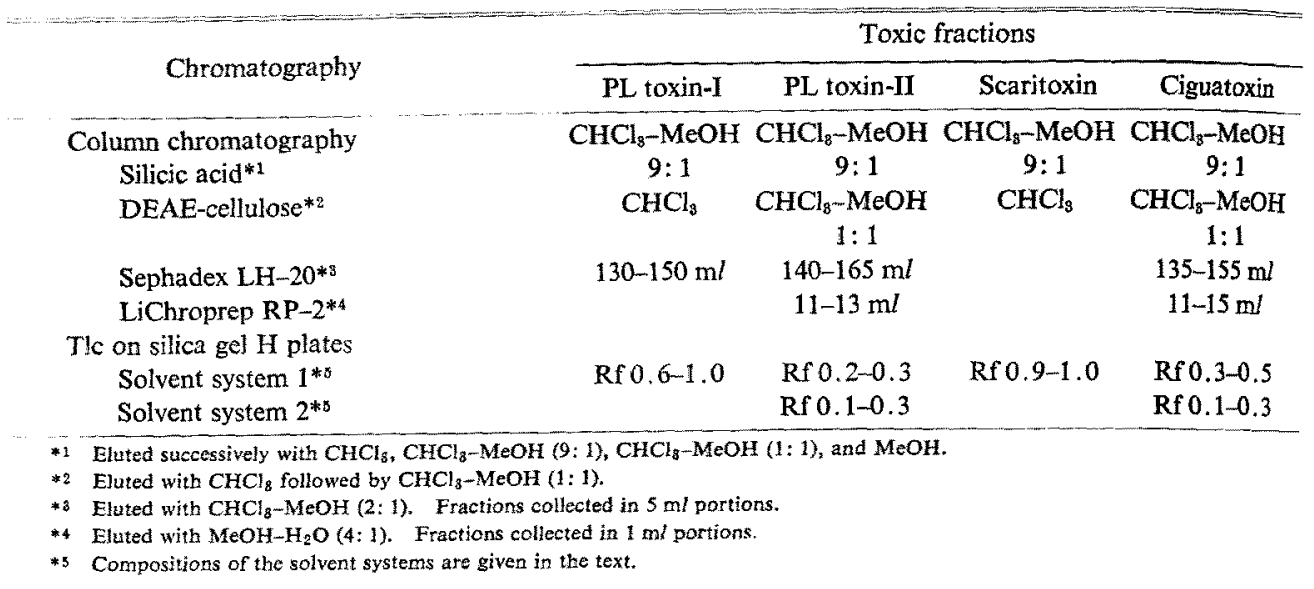

production of planktonic dinoflagellates, especially on the bloom forming species. In contrast, little work has been done to test the benthic species as the potential source of toxins. The confirmation of toxins in P. lima and Amphidinium sp, in the present study and the previous finding of a toxic species $G$. toxicus suggested that other toxic species will be found if searchs are continued. It is quite likely that toxins produced by such species are taken up by herbivores, grazers, and detritus feeders, as in the case of ciguatera. Thus, benthic dinoflagellate should be taken into consideration when origin of toxins is sought in coral reef community.

Especially interesting and important in this study is the fact that PL toxin-I and II are hardly distinguishable in chromatographic properties from scaritoxin and ciguatoxin prepared from ciguateric fish. Occurrence of such ciguatoxin- and scaritoxin-like toxins in $P$. lima raises a critical question as to the origin of ciguatoxin and scaritoxin in the nature, especially in view of the fact that laboratory culture of $G$. toxicus does not produce ciguatoxin under the same condition ${ }^{11}$. However, the scarce presence of $P$. lima in the detritus samples which were confirmed to contain ciguatoxin makes the assumption doubtful that this organism is the main source of ciguatoxin and scaritoxin. Wide distribution of $P$. lima in places where ciguatera has never been reported also offers circumstantial evidence against the above assumption. However, we like to refrain from drawing conclusion untill more confrmative data become available as to the identities of the toxins.

\section{Acknowledgements}

We are grateful to Dr. J. M. HurTeL, of Institut de Recherche Medicale "Louis Malarde" for undertaking the initial isolation of some of the organisms. This study was supported by the grant from the Ministry of Education.

\section{References}

1) B. W. Halstead: Poisonous and Venomons Marine Animals of the World, Vol. 1-3, U.S. Printing Office, Washington, D. C., 1965, 1967, 1970.

2) Y. Hashrmoto: Marine Toxins and Other Bioactive Marine Metabolites, Japan Scientific Socity Press, Tokyo, 1979.

3) T. YaSumoto, I. NakAJIMA, R. Bagnis, and R. ADACHI: Bull. Japan. Soc. Sci. Fish., 43, 1021$1026(1977)$.

4) T. YasUmoto, R. Bagnis, and J. P. Vernoux: Bull. Japan. Soc. Sci. Fish., 42, 359-365 (1976).

5) T. Yasumoto, I. Nakatima, F. Chungue, and R. BaGnIs: Bull. Japan. Soc. Sci. Fish., 43, 69-74 (1977).

6) T. YASUMOTO and Y. KotaKI: Bull. Japan. Soc. Sci. Fish., 43, 207-211 (1977).

7) T. YasuMoto: in "Animal, Plant, and Microbial Toxins" (ed. by A. OHSAKA, K. HAYASH, and Y. Sawal), Vol. 1, Plenum Publishing Corporation, New York, 1976, pp. 311-318.

8) T. NoGuchI, S. KoNosu, and Y. Hashimoto: Toxicon, 7, 325-326 (1969).

9) Y.F.TEH and J. E. Gardiner: Toxicon, 12, 603-610 (1974).

10) L. Provasoli: in "Cultures and Collections of 
Algae" (Proceedings of the U. S.-Japan Conference held at Hakone, Sep. 12-15, 1966, ed. by A. Watanabe and A. Hattori), Japan. Soc. Plant Physiol., Tokyo, pp. 63-75.
11) T. Yasumoto, I. Nakajima, Y. Oshima, and R. BAGNIS: in "Toxic Dinoflagellate Blooms" (ed. by D. L. TAYLoR and H. H. Seliger), Elsevier North-Holland, New York, 1979, pp. 65-70. 